\title{
THE INFLUENCE OF TEMPERATURE ON THE BREEDING AND THE MOULTING ACTIVITIES OF SOME WARM-WATER SPECIES OF OPERCULATE BARNACLES
}

\author{
By Bhupendra Patel and D. J. Crisp \\ Marine Biology Station, Menai Bridge, Anglesey
}

(Text-figs. I and 2)

Thorson (1946) considered in detail the earlier views of Appellöf (1912), Orton (1920) and Runnström (1928) that breeding activities of the majority of marine organisms were controlled by the temperature of the sea and referred to this as Orton's rule. Recently Crisp (1954) and Qasim (1956) also reviewed the existing literature on this subject in relation to barnacles and fish. By considering the seasonal availability of planktonic food in conjunction with Orton's rule, they explained why tropical species inhabiting cool temperate waters have a breeding season confined to the warmer months, whereas boreo-arctic species throughout their whole range breed only during colder months.

Loosanoff \& Davis (1950) succeeded in bringing the bivalve mollusc Venus mercenaria into the spawning condition by gradually raising the water temperature and providing suitable food. Patel (1959) maintained specimens of Lepas anatifera L. under laboratory conditions, raised the temperature, and fed them on Artemia larvae and thereby induced the species to breed. On the other hand, Crisp (1957) reported moderate success in causing the breeding of certain boreo-arctic barnacles during the period when the natural population was not breeding by lowering the temperature.

It was considered desirable to have a liberal supply of fertilized egg masses, larvae and cyprids of the commoner fouling organisms, especially of cirripedes, at all the seasons of the year for conducting experimental work. The following experiments were carried out to induce these animals to breed outside the normal breeding period of the natural population. Simultaneously, consideration was given to the influence of temperature on moulting rhythm, cirral activity and egg size.

Tropical or subtropical species of operculate barnacles inhabiting British waters, namely Chthamalus stellatus (Poli), Elminius modestus Darwin, Balanus perforatus Bruguière and B. amphitrite var. denticulata (Broch), were selected for the investigation. 


\section{MATERIAL AND METHODS}

Specimens of Chthamalus stellatus were collected on pieces of rock from Aberffraw, Anglesey; Elminius modestus on mussels attached to the piles of Bangor pier in the Menai Straits; Balanus perforatus on rock chippings from the coast of the Gower peninsula; and B. amphitrite on pieces of glass bottle from the warm docks at Swansea. All specimens were obtained during the winter.

Immediately after the sample had been collected, about 70 to 100 individuals of each species were examined for the presence of egg masses. Of the four species only Elminius modestus could not be obtained normally free of embryos in the cooler months of the year (Crisp \& Davies, 1955). To obtain E. modestus without egg masses all the individuals settled on each Mytilus shell, except for one specimen of mature size, were removed. The isolated specimens so obtained were kept in separate dishes to prevent further fertilization and were fed for about a fortnight to encourage liberation (Crisp, 1956; Crisp \& Spencer, 1958). Individuals which liberated nauplii during isolation were then certain to be empty, since self-fertilization does not occur in this species (Barnes \& Crisp, 1956). They were then used to investigate the induction of further breeding. The other three species were found to be entirely free of egg masses at the season when the experiments were conducted.

About 20 to 30 individuals of each species were kept in 6 in. diameter glass crystallizing dishes and maintained at a series of different temperatures, each one varying by not more than $\pm 2^{\circ} \mathrm{C}$. The temperatures were recorded each day throughout the experiments and a mean value calculated at the end.

Two identical groups of animals belonging to the same species were selected for each experiment at each temperature, except for E. modestus which had to be given a preliminary feeding as described above. One group was fed liberally on Artemia larvae and the other group was kept without food. The large quantities of Artemia larvae required were hatched from commercially available Artemia eggs in a warmed $3 \times 1 \frac{1}{2} \mathrm{ft}$. glass tank containing sea water and continuously aerated to keep the eggs circulating throughout the tank. Hatched larvae were strained off, and transferred daily to the dishes containing barnacles, when fresh sea water, brought to the required temperature was added. Throughout the experiment the water surrounding the barnacles was freely aerated both to oxygenate it, and to keep the food moving over the barnacles, which then fed by simply extending the cirri (Southward \& Crisp, 1959).

Cast skins, expelled egg masses and any liberations of nauplii were carefully noted, a separate record for each dish being kept. After an interval of 8Io days at each temperature a few animals from each dish were examined to see whether any had become fertilized. If so, the stages of development of the fertilized egg masses were determined, using the categories given by Crisp 
(1954). The condition of the ovary of all unfertilized specimens was visually determined, the stage of ovarian development being divided into five categories and points assigned as shown in Table I. A mean ovary index was obtained for the samples taken from each dish.

$\begin{array}{cc}\text { TABLE 1. STAGES OF OVARIAN DEVELOPMENT } \\ \text { Condition of ovary } & \begin{array}{c}\text { Ovary index } \\ \text { score }\end{array} \\ \text { Fertilized egg masses } & 4 \\ \text { Well-developed ovary filling mantle space } & 3 \\ \text { Moderately developed ovary } & 2 \\ \text { Slightly developed ovary with minute eggs } & \text { I } \\ \text { No ovarian development observed } & \text { ○ }\end{array}$

The lengths and breadths of the fertilized eggs were measured in microns. Since the fertilized egg was approximately a prolate spheroid, the volume was calculated as $4 / 3 \pi a b^{2}$, where $a=\frac{1}{2}$ length and $b=\frac{1}{2}$ breadth.

To study the influence of temperature on the size of released nauplii (stage I), normally fertilized $E$. modestus were collected from the field. Egg masses produced by each parent were divided into three batches, each of which was then incubated in vitro at different temperatures following the methods described by Patel \& Crisp (1960). Immediately after being released stage I nauplii were preserved in $5 \%$ sea water formaldehyde and their dimensions measured.

These experiments were conducted during December I957 to February I 958 and during December 1958 to February 1959, when the natural population of all the species was dormant and generally had poorly developed gonads. The results of both the years were identical and were therefore combined in the tabulated results.

\section{EFFECT OF TEMPERATURE ON BREEDING}

The results on the influence of temperature on the breeding activities of animals maintained at a series of different temperatures (as described above) are shown in Table 2 . Breeding activity may be judged from the percentage of individuals fertilized at the end of the experiments at each temperature. It will be evident from Table 2 that the fed specimens of all the four species, though having scarcely any development of the gonads at the outset, developed gonads within a short time and soon reached breeding condition. In most cases they were able to breed after being kept for only $2-3$ weeks at their breeding temperature. Both the percentage of the individuals carrying embryos and also, in general, the ovary index increased as the temperature was raised above the critical minimum value for breeding. This minimum varied with each species, thus $B$. amphitrite started breeding activity at $\mathrm{I} 7-\mathrm{I} 8^{\circ} \mathrm{C}, B$. perforatus and $C$. stellatus at $15-16^{\circ} \mathrm{C}$ and $E$. modestus was found 
TABLE 2. THE EFFECT OF TEMPERATURE AND FEEDING ON THE MEAN INDEX OF DEVELOPMENT OF THE OVARY, ON THE PERCENTAGE OF FERTILIZED INDIVIDUALS AND ON THE NUMBER OF BROODS IN BARNACLES

Fed

\begin{tabular}{|c|c|c|c|c|c|c|c|c|}
\hline $\begin{array}{l}\text { Mean } \\
\text { temperature } \\
\left({ }^{\circ} \mathrm{C}\right)\end{array}$ & $\begin{array}{c}\text { No. of } \\
\text { days } \\
\text { animals } \\
\text { were kept at } \\
\text { stated } \\
\text { tempera- } \\
\text { ture }\end{array}$ & $\begin{array}{l} \\
\% \\
\text { ferti- } \\
\text { lized }\end{array}$ & $\begin{array}{l}\text { Mean } \\
\text { ovary } \\
\text { index }\end{array}$ & $\begin{array}{l}\text { No. of } t \\
\text { broods }\end{array}$ & $\begin{array}{l}\text { No. of } \\
\text { days } \\
\text { animals } \\
\text { kept at } \\
\text { stated } \\
\text { tempera- } \\
\text { ture }\end{array}$ & $\begin{array}{l}\% \\
\text { ferti- } \\
\text { lized }\end{array}$ & $\begin{array}{l}\text { Mean } \\
\text { ovary } \\
\text { index }\end{array}$ & $\begin{array}{l}\text { No. of } \\
\text { broods }\end{array}$ \\
\hline \multicolumn{9}{|c|}{ (a) Chthamalus stellatus } \\
\hline 32 & 15 & 10 & $2 \cdot I$ & I & 25 & $\circ$ & $\mathrm{I} \cdot \mathrm{O}$ & $\circ$ \\
\hline 30 & 15 & 36 & $2 \cdot 7$ & I & - & - & - & - \\
\hline 28 & 15 & 30 & 3.I & I & 25 & 0 & $I \cdot 2$ & $\circ$ \\
\hline 25 & 25 & 20 & 3.6 & I & 35 & o & I.O & 0 \\
\hline 20 & 25 & 60 & $3 \cdot 4$ & I & 35 & 0 & I.O & 0 \\
\hline 15 & 25 & 12 & $2 \cdot 7$ & I & 35 & 0 & $\mathrm{I} \cdot \mathrm{O}$ & 0 \\
\hline & 35 & 0 & I. 6 & 0 & & - & - & - \\
\hline 6 & 40 & o & $I \cdot 2$ & o & 40 & o & 0.5 & o \\
\hline \multicolumn{9}{|c|}{ (b) Balanus perforatus } \\
\hline $3 \mathrm{I} \cdot 5$ & I0 & 0 & - & $\star$ & IO & o & - & $\star$ \\
\hline $28 \cdot 0$ & 20 & 53 & 3.5 & I & 25 & o & $\mathrm{I} \cdot \mathrm{O}$ & o \\
\hline 23.5 & 20 & 77 & 3.8 & I & 25 & 0 & I. 5 & o \\
\hline 19.0 & 20 & 60 & 3.5 & I & 25 & 0 & $\mathrm{I} \cdot 5$ & 0 \\
\hline 15.0 & 35 & 5 & $2 \cdot 4$ & I & 40 & 0 & I.O & 0 \\
\hline 13.0 & 40 & 0 & 2.0 & o & 40 & 0 & 0.8 & 0 \\
\hline 10.0 & 40 & 0 & $I \cdot 2$ & 0 & - & - & - & - \\
\hline $6 \cdot 0$ & 40 & 0 & 0.9 & o & 40 & 0 & 0.5 & 0 \\
\hline
\end{tabular}

* Indicates specimens died within 8-ro days.

\begin{tabular}{|c|c|c|c|c|c|c|c|c|}
\hline $3 I \cdot 5$ & 40 & 100 & 4.0 & 2 & 45 & 0 & 0.5 & 0 \\
\hline 27.5 & 40 & 100 & 4.0 & 2 & 45 & 0 & 0.5 & 0 \\
\hline 24.5 & 40 & 100 & 4.0 & 2 & & - & - & - \\
\hline 22.5 & 40 & 100 & 4.0 & 2 & 45 & 0 & 0.7 & 0 \\
\hline 19.5 & 20 & 73 & 3.6 & I & - & - & - & \\
\hline 17.5 & 20 & 34 & 3.0 & I & 45 & 0 & 1.0 & 0 \\
\hline 4.5 & 45 & 0 & $2 \cdot 0$ & 0 & 45 & 0 & 0.8 & 0 \\
\hline $11 \cdot 5$ & 35 & 0 & 2.0 & ○ & & - & - & - \\
\hline $7 \cdot 5$ & 35 & 0 & $I \cdot O$ & 0 & - & - & - & - \\
\hline
\end{tabular}

(d) Elminius modestus

(All animals fed throughout experiment.)

No. of days $\begin{array}{cc}\text { Mean } & \text { animals were } \\ \text { kept at stated }\end{array}$ $\left({ }^{\circ} \mathrm{C}\right)$ temperature

fertilized

35
93
90
70
54

Mean ovary index

$2 \cdot 9$

3.9

3.9

3.7

3. 3
No, of broods 
fertilized at $8^{\circ}-9^{\circ} \mathrm{C}$. Above the optimum temperature for breeding, the percentage of fertilized individuals and the mean ovary index fell. Thus $B$. perforatus bred at an optimum rate between $22^{\circ}$ and $23^{\circ} \mathrm{C}$, and continued to breed up to $27^{\circ}-28^{\circ} \mathrm{C}$. At even higher temperatures $\left(30^{\circ}-32^{\circ} \mathrm{C}\right)$ animals survived for only 7 -10 days and did not breed. C. stellatus did not reach its optimum until $24^{\circ}-25^{\circ} \mathrm{C}$, and continued producing broods up to $30^{\circ}-32^{\circ} \mathrm{C}$, though a lower percentage of the population was found to be carrying eggs at this temperature. In $B$. amphitrite all the experimental individuals bred readily between $22^{\circ}$ and $32^{\circ} \mathrm{C}$, and on one occasion when the thermostat failed they withstood temperatures of the order $38^{\circ}-40^{\circ} \mathrm{C}$ for over $24 \mathrm{~h}$. Individuals of $E$. modestus reached their optimum rate at $22^{\circ}-25^{\circ} \mathrm{C}$, and both the percentage of fertilized individuals and the mean ovary index fell considerably at $30^{\circ}-31^{\circ} \mathrm{C}$.

\section{EFFECT OF NUTRITION ON BREEDING}

It can be seen from Table 2 that, within the characteristic temperature range of breeding for any given species, only those groups of individuals which were given food developed gonads rapidly and bred readily. When barnacles were fed on Artemia larvae the newly developed ovary assumed an abnormal pinkish tint instead of its usual yellow colour. Similar colour changes, but more pronounced, were observed in artificially fed Lepas anatifera (Patel, I959). The operculate barnacles, unlike Lepas however, could live without food for long periods. These starved individuals failed to develop the gonads, as is evident from the continuing low mean ovary index. It should be borne in mind that these animals were collected at the season when the feeding activity and reserves were already at a minimum. Had they been collected just before the normal breeding season, when the gonads would have been more fully developed, a proportion at least of the observed specimens would doubtless have bred on raising the temperature. This was later found to be so with $C$. stellatus and $B$. perforatus during May and June, respectively.

To confirm that nutrition played a major role in allowing breeding to commence, some of the starved individuals of the species B. amphitrite, $B$. perforatus and C. stellatus, which had not fertilized even after having been kept for 30-40 days above the critical breeding temperatures, were fed liberally on Artemia larvae. Within I8-20 days these specimens entered the breeding condition and fertilized readily. The mean ovary index was also accordingly increased.

The temperature above which breeding begins in each species agrees well with the natural breeding season and the geographical distribution. E. modestus which breeds throughout the year in south-west England (Crisp \& Davies, I955) and whose distribution extends to the colder east coast of Britain, has the lowest critical breeding temperature of $8^{\circ}-9^{\circ}$ C. C. stellatus, which breeds only from May to September (Crisp, 1950) and whose distribution 
extends up the west and north coasts of Scotland but not to the east coast, has the next highest breeding temperature of $15^{\circ}-16^{\circ} \mathrm{C}$. B. perforatus has a breeding range whose lower limit is about equal to that of $C$. stellatus, but, since its habitat is lower on the shore, it does not benefit to the same degree as C. stellatus from the sun's heat and the increase in temperature that occurs in spring. This may explain its later onset of breeding (July) and its more restricted distribution, which extends only to St David's Head (Norris \& Crisp, 1953). B. amphitrite, with a critical breeding point of $17^{\circ}-18^{\circ} \mathrm{C}$, is a more tropical form, found in Britain only in exceptionally warm areas, such as power station effluents, and does not occur on the open coast further north than the Charente area in the Bay of Biscay (Bishop, Crisp, Fischer-Piette \& Prenant, 1957).

The upper temperature limits of breeding are not far removed from the upper limits of survival of each species. The most sensitive of the four was $B$. perforatus which could not survive temperatures in excess of $30^{\circ} \mathrm{C}$ for long, and ceased to breed in this range. C. stellatus survives at the level of high water springs where it may be exposed to temperatures of at least $38^{\circ} \mathrm{C}$ (Southward, 1955). This species continued to breed at $32^{\circ} \mathrm{C}$ but, as only $10 \%$ contained fertilized eggs at this temperature, it is unlikely that breeding would have continued at temperatures much in excess of this. E. modestus, which can survive at levels almost as high as those occupied by C. stellatus, was not tested above $30^{\circ} \mathrm{C}$; the fall in the percentage fertilized at this temperature suggests, however, that its upper limit is close to that of C. stellatus. B. amphitrite, the species most tolerant of high water temperatures, showed no fall-off in breeding at $31.5^{\circ} \mathrm{C}$, all individuals containing embryos.

\section{INFLUENCE OF TEMPERATURE AND NUTRITION ON THE MOULTING RHYTHM}

Crisp \& Patel $(1958,1960)$ have reported that the frequency of moulting was dependent on the temperatures during and of nutrition prior to the experimental period. During the present series of experiments the frequency of moulting at different temperatures was measured for fed and starved individuals of all the four species. The results are illustrated in Fig. I in which the rate of moulting per barnacle per day is plotted against temperature, together with Southward's (1955, 1957) observations on their cirral activity.

The temperature optimum of moulting activity was generally slightly lower than that of cirral activity. The difference may well be explained by the difference in duration of the two types of experiments. Experiments on cirral beats could be completed in a much shorter time than those on moulting which required IO-I5 days. At the upper limit of temperature tolerance, therefore, rates of cirral beat could be measured before the elevated temper- 

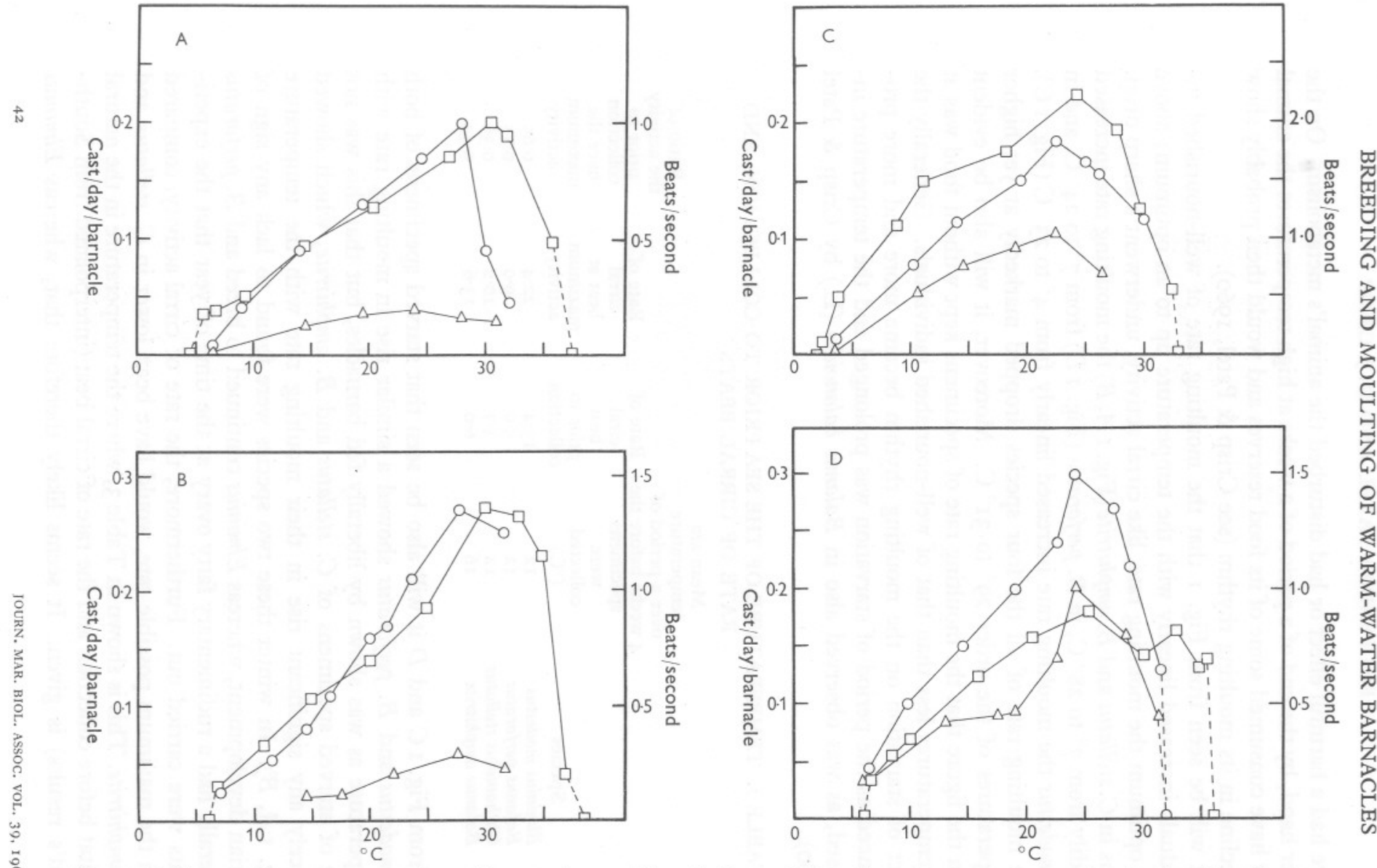

Fig. I. Influence of temperature and nutrition on the moulting rhythm and the effect of temperature on the cirral activity (the latter is taken from Southward, 1955 and 1957) $(A)$ Chthamalus stellatus, $(B)$ Balanus amphitrite var. denticulata, $(C)$ Elminius modestus and (D) Balanus perforatus. O Indicates moulting rate of fed specimens. $\triangle$ Indicates moulting rate of starved specimens. $\square$ Indicates the rate of cirral beating. (Note: In order to accommodate the high rate of beating in Elminius modestus, the scale on the ordinate of Fig. IC showing the rate of beat has been reduced in comparison with the scales in Fig. I $A, B$ and $D$.) 
ature had a harmful effect or had disturbed the animal's metabolism. On the other hand, by the end of a period of 2 weeks at high temperatures the animal may have consumed some of its food reserves and would then probably show a decline in its moulting rhythm (see Crisp \& Patel, 1960).

It will be seen from Fig. I that the moulting rate of well-nourished individuals increased linearly with the temperature up to an optimum; above this optimum the moulting rate, like cirral activity, underwent a sharp drop. Thus in C.stellatus and B. amphitrite (Fig. I $A, B$ ) the moulting rate increased steadily from $7^{\circ}$ to $28^{\circ} \mathrm{C}$, in B. perforatus (Fig. I $D$ ) from $7^{\circ}$ to $24^{\circ} \mathrm{C}$, and in E. modestus the moulting rate increased linearly from $4^{\circ}$ to $23^{\circ} \mathrm{C}$ (Fig. I C). The moulting rate of all the four species dropped markedly at yet higher temperatures of the order $29^{\circ}$ to $3 \mathrm{I}^{\circ} \mathrm{C}$. Moreover, it will also be evident from the figure that the moulting rate of specimens kept without food was at all temperatures less than that of well-nourished individuals. Generally the effect of starvation on the moulting rhythm became more and more pronounced as the period of starvation was prolonged and the temperature increased, as was observed also in Balanus balanoides (L.) by Crisp \& Patel (1960).

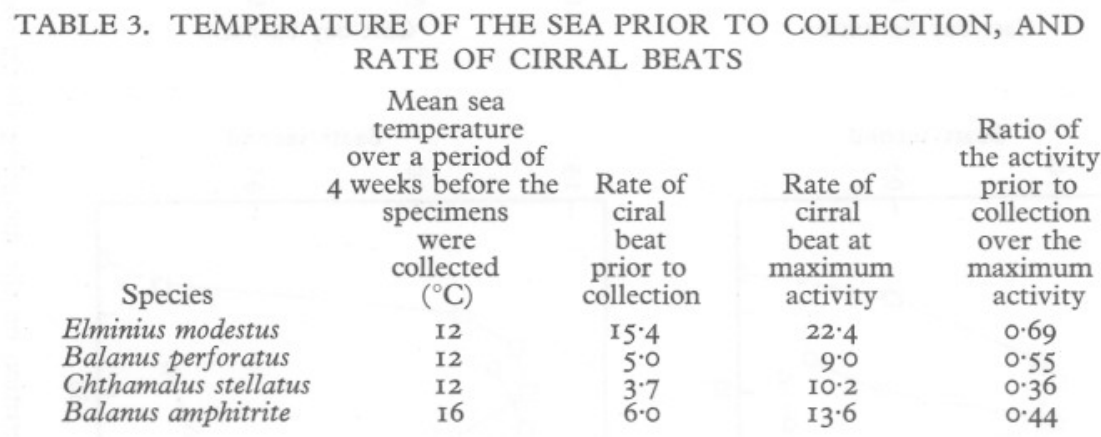

From Fig. I $C$ and $D$ it will also be seen that starved specimens of both $E$. modestus and $B$. perforatus showed a similar rise in moulting rate with temperature as was shown by liberally fed barnacles, but that this was not true of starved specimens of $C$. stellatus and $B$. amphitrite, which showed scarcely any significant rise in their moulting rate with the temperature (Fig. I $A, B$ ). In winter these two species were found to lack any sign of ovarian development, whereas Elminius continued to breed and B. perforatus generally had a rudimentary fatty ovary at the time of year that the experiments were carried out. Furthermore, the rate of cirral activity, compared with the maximum possible rate, would have been lower in C. stellatus and B. amphitrite. This is shown in Table 3, where the temperature in the natural habitat before collection and the rate of cirral beat (interpolated from Southward's results) is given. It seems likely therefore that, whereas Elminius 
modestus and $B$. perforatus may have been feeding at a sufficient rate to maintain their reserves in some degree, C. stellatus and B. amphitrite had been feeding more sluggishly in relation to their optimum, and were in a more starved condition. In consequence starved individuals of these two species were probably unable to maintain a moulting rate in step with the rise in temperature.

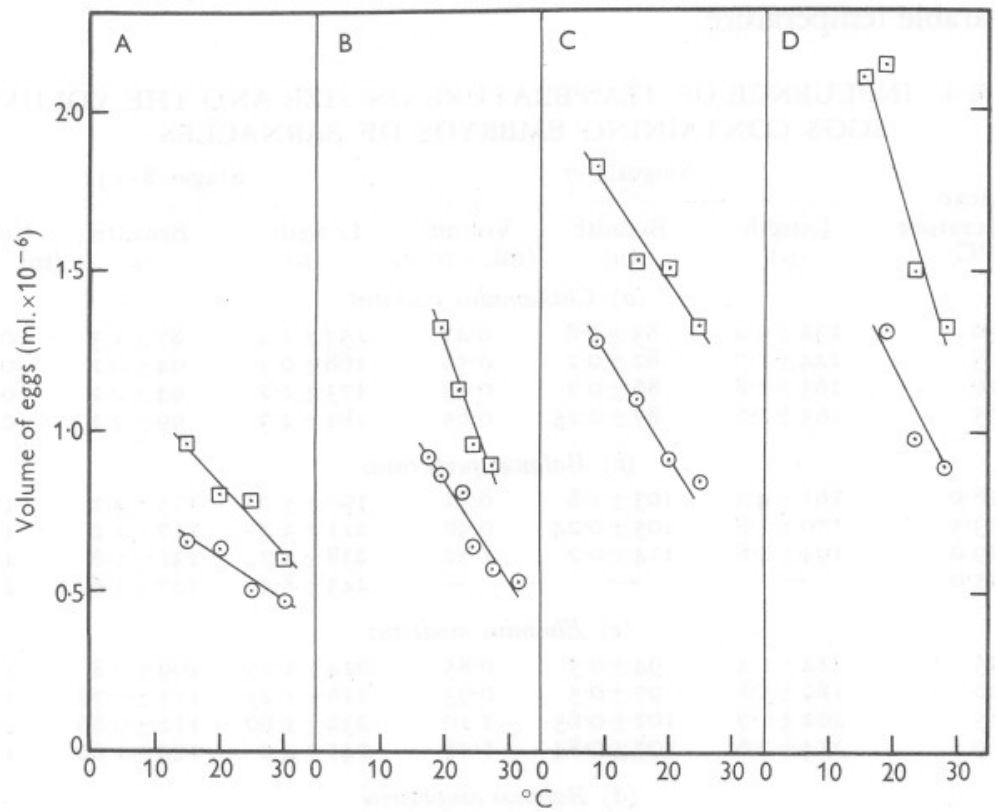

Fig. 2. Effect of temperature on the volume of eggs $(A)$ Chthamalus stellatus, $(B)$ Balanus amphitrite var. denticulata, $(C)$ Elminius modestus and $(D)$ Balanus perforatus. $\odot$ indicates volumes of eggs containing early stage embryos. Indicates volumes of eggs containing late stage embryos.

\section{TEMPERATURE AND EGG SIZE}

The dimensions of fertilized eggs from the adults kept and fed at a series of different temperatures during the period that the ovary and subsequent brood were developing, are given in Table 4 . The mean lengths, breadths and deduced volumes are shown together with the corresponding standard errors. The egg volumes are plotted in Fig. 2, against the temperature of development. In all the four species at all temperatures the volume of the eggs increased as the embryos developed. Furthermore, the volumes of both early (stages I to 7) and late stages (stages 8 to I3) increased with the lowering of the temperature at which they had developed as ova. Generally, the breadth remained more or less constant but the length varied considerably. Identical results were reported by Patel (1959) in Lepas anatifera, and Crisp (I960) 
found a significant change in volume of the fertilized eggs of the boreo-arctic species $B$. balanoides collected from different latitudes. The size of the eggs decreased from north to south, i.e. from colder to warmer water. Earlier Crisp (1954) had shown that the dimensions of fertilized eggs in boreoarctic species of operculate cirripedes were in general larger than those of their relatives from the lower latitudes. The measurements given in Table 4 are approximately of the same value as given by Crisp (1954) at the nearest comparable temperature.

TABLE 4. INFLUENCE OF TEMPERATURE ON SIZE AND THE VOLUME OF EGGS CONTAINING EMBRYOS OF BARNACLES

\begin{tabular}{|c|c|c|c|c|c|c|}
\hline \multirow{2}{*}{$\begin{array}{c}\text { Mean } \\
\text { temperature } \\
\left({ }^{\circ} \mathrm{C}\right)\end{array}$} & \multicolumn{3}{|c|}{ Stages $\mathrm{I}-7$} & \multicolumn{3}{|c|}{ Stages $8-I_{3}$} \\
\hline & $\begin{array}{l}\text { Length } \\
\qquad(\mu)\end{array}$ & $\begin{array}{l}\text { Breadth } \\
\quad(\mu)\end{array}$ & $\begin{array}{l}\text { Volume } \\
\left(\mathrm{ml} . \times \mathrm{IO}^{-6}\right)\end{array}$ & $\begin{array}{l}\text { Length } \\
\qquad(\mu)\end{array}$ & $\begin{array}{l}\text { Breadth } \\
\qquad(\mu)\end{array}$ & $\begin{array}{l}\text { Volum } \\
\text { (ml. } \times \text { IO }^{-}\end{array}$ \\
\hline \multicolumn{7}{|c|}{ (a) Chthamalus stellatus } \\
\hline 30 & $132 \pm 5 \cdot 4$ & $83 \pm 0.8$ & 0.47 & I $54 \pm 2 \cdot 4$ & $87 \pm I \cdot 3$ & 0.60 \\
\hline 25 & $144 \pm I \cdot 7$ & $82 \pm 0.2$ & 0.50 & $168 \pm 0.3$ & $94 \pm 0.2$ & 0.78 \\
\hline 20 & $I 63 \pm I \cdot 8$ & $86 \pm 0.2$ & 0.63 & $I 73 \pm I \cdot 2$ & $94 \pm 0.2$ & 0.80 \\
\hline I5 & $165 \pm I \cdot 6$ & $87 \pm 0.25$ & 0.65 & $184 \pm 4 \cdot 3$ & $99 \pm 2 \cdot 2$ & 0.95 \\
\hline \multicolumn{7}{|c|}{ (b) Balanus perforatus } \\
\hline $28 \cdot 0$ & $I 6 I \pm 4 \cdot 2$ & $103 \pm I \cdot 8$ & $0.9 \mathrm{I}$ & $193 \pm 5^{\circ} 0$ & II $5 \pm 2 \cdot 2$ & I.33 \\
\hline 23.5 & $170 \pm I \cdot 8$ & $105 \pm 0.24$ & 0.98 & $2 I I \pm 3 \cdot 2$ & II $7 \pm I \cdot 2$ & $I \cdot 50$ \\
\hline 19.0 & $194 \pm \mathrm{I} \cdot 8$ & $114 \pm 0.2$ & $I \cdot 32$ & $238 \pm 3 \cdot 7$ & $131 \pm 1 \cdot 6$ & $2 \cdot 14$ \\
\hline $15 \cdot 0$ & - & - & - & $245 \pm 8 \cdot 5$ & $127 \pm 3.6$ & $2 \cdot 10$ \\
\hline \multicolumn{7}{|c|}{ (c) Elminius modestus } \\
\hline 25 & $I 84 \pm I \cdot 4$ & $94 \pm 0.5$ & 0.85 & $214 \pm I \cdot 25$ & $109 \pm 0.8$ & $I \cdot 33$ \\
\hline 20 & $189 \pm 5 \cdot 8$ & $97 \pm 0.5$ & 0.93 & $226 \pm I \cdot 25$ & $113 \pm 0.78$ & $I \cdot 5 \mathrm{I}$ \\
\hline I5 & $202 \pm I \cdot 7$ & $102 \pm 0.65$ & I. IO & $232 \pm I \cdot 80$ & II \pm 0.86 & $\mathrm{I} \cdot 53$ \\
\hline 9 & $214 \pm 2 \cdot 6$ & $107 \pm 0.84$ & $I \cdot 28$ & $24 \mathrm{I} \pm 4.0$ & $120 \pm 2 \cdot 60$ & $\mathrm{I} \cdot 82$ \\
\hline \multicolumn{7}{|c|}{ (d) Balanus amphitrite } \\
\hline $3 I \cdot 5$ & $127 \pm 6 \cdot 0$ & $88 \pm 2 \cdot 0$ & 0.53 & - & - & - \\
\hline $27 \cdot 5$ & $136 \pm 3 \cdot 7$ & $89 \pm 0.3$ & 0.57 & $162 \pm 5 \cdot 0$ & $103 \pm 3.0$ & 0.90 \\
\hline $24 \cdot 5$ & $145 \pm 3.5$ & $92 \pm 0.4$ & 0.64 & $173 \pm 2 \cdot 0$ & $103 \pm I \cdot 4$ & 0.96 \\
\hline $22 \cdot 5$ & $159 \pm 2.8$ & $99 \pm 0.2$ & $0.8 \mathrm{I}$ & $178 \pm 2.8$ & $110 \pm I \cdot 2$ & $I \cdot I 3$ \\
\hline $19 \cdot 5$ & $165 \pm I \cdot 5$ & $100 \pm I \cdot 2$ & 0.86 & $184 \pm 3.0$ & II $7 \pm I \cdot 4$ & $I \cdot 32$ \\
\hline $17 \cdot 5$ & $167 \pm 2 \cdot 4$ & $102 \pm 0.8$ & 0.92 & & - & - \\
\hline
\end{tabular}

It will be seen that in three of the four species the influence of temperature on egg size is accentuated in the later embryonic stages, though the curve for $E$. modestus (Fig. $2 C$ ) has a similar slope for both early and late stages. If egg size was related to the size of the developing embryo these changes in slope suggest that temperature influences not only the initial size of the ova but also the amount of embryonic growth, both effects determining the ultimate size which the developing embryo can attain. In order to test the influence of temperature during development on the ultimate size of the embryo, fertilized eggs of $E$. modestus, which had been oviposited by the same parent in July at the prevailing sea temperature, were incubated in vitro at a series of different temperatures. The first stage nauplii formed showed a variation 
in size (Table 5). That those which developed at the highest temperature were the smallest in size confirms that in barnacles the embryos are reduced in size if they undergo embryonic development at a higher temperature.

Our results agree with those obtained by Gray $(1928 a, b)$ who, in an essentially similar experiment reported that the eggs of Salmo fario from the same female, when incubated at a series of different temperatures hatched into fry of different size. Those reared at a higher temperature were smaller than those incubated towards the lower limit of normal development. However, both our findings and Gray's differ from those of Loosanoff (I959) who used

TABLE 5. INFLUENCE OF TEMPERATURE ON LENGTHS AND BREADTHS OF STAGE I NAUPLII OF ELMINIUS MODESTUS. EGG MASSES REMOVED FROM ONE PARENT WERE INCUBATED IN VITRO AT THE FOLLOWING DIFFERENT TEMPERATURES

\begin{tabular}{|c|c|c|c|c|c|c|c|}
\hline \multirow[b]{2}{*}{$\begin{array}{c}\text { Parent } \\
\text { no. }\end{array}$} & \multirow{2}{*}{$\begin{array}{l}\text { Stage of } \\
\text { development } \\
\text { of embryos } \\
\text { at beginning } \\
\text { of } \\
\text { experiment }\end{array}$} & \multicolumn{2}{|c|}{$\mathrm{II}^{\circ} \mathrm{C}$} & \multicolumn{2}{|c|}{$16^{\circ} \mathrm{C}$} & \multicolumn{2}{|c|}{$23^{\circ} \mathrm{C}$} \\
\hline & & $\underset{(\mu)}{\text { Length }}$ & $\underset{(\mu)}{\text { Breadth }}$ & $\underset{(\mu)}{\text { Length }}$ & $\underset{(\mu)}{\text { Breadth }}$ & $\underset{(\mu)}{\text { Length }}$ & $\begin{array}{c}\text { Breadth } \\
(\mu)\end{array}$ \\
\hline I & $3-4$ & $268 \pm I \cdot 5$ & I $16 \pm 0.5$ & $252 \pm 2.5$ & II $5 \pm 0.6$ & $229 \pm 3.9$ & $108 \pm I \cdot 3$ \\
\hline 2 & & $259 \pm \mathrm{I} \cdot \mathrm{I}$ & & $247 \pm 2 \cdot 6$ & & & \\
\hline 3 & $8-9$ & $260 \pm I \cdot I$ & $118 \pm 1 \cdot 2$ & $252 \pm 2.0$ & II \pm 2.4 & $246 \pm 0.5$ & II $4 \pm 0.7$ \\
\hline
\end{tabular}

eggs of Venus (Mercenaria) mercenaria which had been artificially induced to spawn during winter. The spawn was maintained at a series of different temperatures. Loosanoff found no significant difference in the final size of the larvae at the time of settlement. However, the results in Fig. 2 of his paper show a drop in size as the temperature was raised above $20^{\circ} \mathrm{C}$ and the failure to observe any size difference may have been due to the great variation in the larval size at each temperature.

The effect of temperature on egg size is common to many other groups of animals. Moore (I942) found eggs of graded diameter in different species of frogs belonging to the genus Rana, the northern forms laying larger eggs than the southern forms. Later the same author reported similar differences in the diameter of fertilized eggs of Rana pipiens inhabiting different latitudes (Moore, I949). Colder conditions not only increase the size attained by the embryos but in many animals lead also to a larger size in the adults. Many observers have noticed that marine organisms belonging to the same species but inhabiting different latitudes grow more slowly but attain a significantly larger size in higher latitudes (for literature see Gunter, I950, 1957).

Although the amount of growth is less at higher temperatures, the rate at which the final condition of maturity is reached is greater, whether the system be a developing oocyte, an embryo, or an adult poikilotherm. Gray's simple and direct explanation for embryos was based on the fact that in this system only a limited amount of nutrient was available as yolk. If the growing tissue 
requires proportionately more energy for maintenance at a higher temperature, less material would inevitably be left over for growth. An exactly analogous explanation for developing oocytes or for adult animals cannot be sustained because in these systems the amount of living matter could, if necessary, be augmented during development to allow for increased metabolic activity. Moreover, even in embryos, there is no obvious reason why rapid development over a shorter time interval should be less efficient and so use more reserve food than slow development over a longer time. In barnacles the size of developing ova does not appear to depend to any significant extent on the nutrition of the parent, for animals which are poorly fed produce fewer, but not necessarily smaller, eggs.

It seems possible that in all three systems development may be controlled by similar basic processes in which the temperature coefficient of differentiation, leading to maturity, is greater than the temperature coefficient of tissue multiplication or growth. These two processes, differentiation and growth, do not therefore keep exactly in step at all temperatures; at low temperatures differentiation is relatively slower leading to a larger mature size, while at high temperatures growth is rapid leading to a smaller size at maturity.

We are grateful to Prof. E. W. Knight-Jones of the Department of Zoology, Swansea, for obtaining for us specimens of B. perforatus and B. amphitrite, and to Dr E. Naylor for supplying us with temperature records of Queen's Dock and other places around the Gower peninsula.

\section{SUMMARY}

Tropical species of operculate cirripedes, including Elminius modestus Darwin, Chthamalus stellatus (Poli), Balanus perforatus Bruguière and B. amphitrite var. denticulata (Broch), collected during the winters of 1957 to 1959, were induced to breed by raising the temperature and feeding liberally on Artemia larvae. Well-nourished specimens of B. perforatus and C. stellatus commenced to breed after being kept for $2-3$ weeks at $15^{\circ}-16^{\circ} \mathrm{C} ; B$. amphitrite required a temperature of $17^{\circ}-18^{\circ} \mathrm{C}$, whereas E. modestus bred at $8^{\circ}-9^{\circ} \mathrm{C}$. The percentage of the specimens bearing embryos increased with the temperature and reached optima lying in all four species between $22^{\circ}$ and $25^{\circ} \mathrm{C}$. The animals continued to breed, though less efficiently, up to temperatures of the order $28^{\circ}-30^{\circ} \mathrm{C}$, the limits varying a little for each species. Only fed individuals produced gonads and broods; those kept without food showed no breeding activity at any temperature even after $4-5$ weeks, but after being fed for 2-3 weeks bred readily. The moulting rate of all four species was dependent both on temperature and on their prior nutrition. The moulting rate of wellfed specimens increased linearly to an optimum and subsequently dropped sharply. The moulting rhythm followed a pattern in relation to temperature 
like that of cirral activity, but generally with a lower optimum temperature. The volume of the fertilized eggs increased during development and was greater the lower the breeding temperature.

\section{REFERENCES}

APPELLÖF, A., I912. Invertebrate bottom fauna of the Norwegian Sea and North Atlantic. In The Depths of the Ocean, by Sir J. Murray and J. Hjort, pp. 457560. London: Macmillan.

BARNES, H. \& CRISP, D. J., I956. Evidence of self fertilization in certain species of barnacles. F. mar. biol. Ass. U.K., Vol. 35, pp. 63I-39.

Bishor, M. W. H., Crisp, D. J., Fischer-PietTe, E. \& Prenant, M., I957. Sur l'eco-, logie des Cirripèdes de la côte atlantique francaise. Bull. Inst. océanogr. Monaco, No. I099, p. I2.

CRISP, D. J., I950. Breeding and distribution of Chthamalus stellatus. Nature, Lond., Vol. I66, p. 311.

— 1954. The breeding of Balanus porcatus (da Costa). F. mar. biol. Ass. U.K., Vol. 33, pp. 473-94.

- 1956. A substance promoting hatching and liberation of young in cirripedes. Nature, Lond., Vol. 178, p. 263.

- 1957. Effect of low temperature on the breeding of marine animals. Nature, Lond., Vol. 179, p. I138.

- 1960. Factors influencing the time of breeding of Balanus balanoides. Oikos, Vol. Io, pp. 275-89.

CRISP, D. J. \& DAVIES, P. A., I955. Observations in vivo on the breeding of Elminius modestus grown on glass slides. F. mar. biol. Ass. U.K., Vol. 34, pp. 357-80.

CrisP, D. J. \& PATEL, B. S., I958. Relation between breeding and ecdysis in Cirripedes. Nature, Lond., Vol. I81, pp. 1078-79.

1960. The moulting cycle in Balanus balanoides L. Biol. Bull., Woods Hole, Vol. II 8, pp. 3I-47.

CRISP, D. J. \& SPENCER, C. P., I958. The control of the hatching process in barnacles. Proc. roy. Soc., B, Vol. I48, pp. 278-99.

Gray, J., I $928 a$. The growth of fish. II. The growth-rate of the embryos of Salmo fario. Brit. F. exp. Biol., Vol. 6, pp. I Io-24.

I $1928 b$. The growth of fish. III. The effect of temperature on the development of the eggs of Salmo fario. Brit. F. exp. Biol., Vol. 6, pp. I25-30.

GunTER, G., I950. Correlation between temperature of water and size of marine fishes on the Atlantic and Gulf coasts of the United States. Copeia, No. 4 (Dec. 22), pp. 298-304.

- 1957. Temperature. In Hedgpeth, J. W. (edit.) Treatise on Marine Ecology and Paleoecology, Vol. I, Ecology. New York: the Geological Society of America Memoir 67, pp. 159-84.

Loosanoff, V. L., I959. The size and shape of metamorphosing larvae of Venus (Mercenaria) mercenaria grown at different temperatures. Biol. Bull., Woods Hole, Vol. II7, pp. 308-I8.

LoosanofF, V. L. \& Davis, H. C., I950. Conditioning V. mercenaria for spawning in winter and breeding its larvae in the laboratory. Biol. Bull., Woods Hole, Vol. 98, pp. 60-65.

Moore, J. A., 1942. The role of temperature in speciation of frogs. Biol. Symp., Vol. 6, pp. 189-213. 
MOORE, J. A., 1949. Geographic variation of adaptive characters in Rana pipiens Schreber. Evolution, Vol. 3, pp. I-24.

NorRIS, E. \& CRISP, D. J. I953. The distribution and planktonic stages of the cirripede Balanus perforatus (Bruguière). Proc. zool. Soc. Lond., Vol. I23, pp. 393409.

ORton, J. H., I920. Sea temperature, breeding and distribution of marine animals. F. mar. biol. Ass. U.K., Vol. I2, pp. 339-66.

PATEL, B., I959. The influence of temperature on the reproduction and moulting of Lepas anatifera L. under laboratory conditions. F. mar. biol. Ass. U.K., Vol. 38, pp. 589-97.

PATEL, B. \& CRISP, D. J., I960. Rates of development of the embryos of several species of barnacles. Physiol. Zoöl., Vol. 33, pp. 104-19.

QASIM, S. Z., I956. Time and duration of the spawning season in some marine Teleosts in relation to their distribution. F. Cons. int. Explor. Mer, Vol. 21 (2), pp. I44-55.

RunNSTRÖM, S., I928. Über die Thermopathie der Fortpflanzung und Entwicklung mariner Tiere in Beziehung zu ihrer geographischen Verbreitung. Bergens Mus. Arb., Naturv. rekke, 1927, No. 2, 67 pp.

SouthWARD, A. J., I955. On the behaviour of barnacles. I. The relation of cirral and other activities to temperature. F. mar. biol. Ass. U.K., Vol. 34, pp. 403-22.

- 1957. On the behaviour of barnacles. III. Further observations on the influence of temperature and age on cirral activity. F. mar. biol. Ass. U.K., Vol. 36, pp. 323-34.

Southward, A. J. \& Crisp, D. J., I959. Modes of cirral activity in barnacles. Proc. XV Int. Congr. Zool. Lond., pp. 295-96.

ThORson, G., 1946. Reproduction and larval development of Danish marine bottom invertebrates with special reference to planktonic larvae in the Sound (Øresund). Medd. Komm. Havunderseg. Kbh., Ser. Plankt., Bd. 4, No. I, 523 pp. 